AJIE - Asian Journal of Innovation and Entrepreneurship

(e-ISSN: 2477-0574 ; p-ISSN: 2477-3824)

Vol. 01, No. 02, May 2016

\title{
ANALISIS TINGKAT BUNGA, INFLASI, LIKUIDITAS, NILAI TUKAR, DAN FINANSIAL YANG MEMPENGARUHI TERHADAP KEUNTUNGAN SAHAM DI BURSA EFEK INDONESIA
}

\author{
Hantono dan Luther Girsang \\ Fakultas Ekonomi, Universitas Prima Indonesia \\ Email: hantono_78@yahoo.com
}

\begin{abstract}
Shares optimal gain is the main purpose of an investor in making an investment in a company's stock. To achieve these objectives, of course, an investor should be to act selectively in assessing various potential companies, one of which is the interest rate, inflation, liquidity, exchange rate, and financial .

The first aim of this study was to determine and analyze whether the interest rate will affect the profits of shares in the Indonesian Stock Exchange, both to study and analyze whether inflation will affect the profits of shares in the Indonesian Stock Exchange in the period 2010-2012, the third to study and analyze liquidity affect profit shares in the Indonesian Stock Exchange in the period 2010-2012, the fourth to identify and analyze the exchange rate will affect the profits of shares in the Indonesian Stock Exchange in the period 2010-2012, the fifth to megetahui and financial analyzes will affect profit shares in the Indonesian Stock Exchange in the period 2010-2012, and the sixth to know and to analyze whether the inflation, liquidity, exchange rate and financial will affect profit shares in the Indonesian Stock Exchange in the period 2010-2012.

Results of this study that the interest rate, inflation, liquidity, exchange rate, and financial influence together to gain share in the Indonesia Stock Exchange, while individually the interest rate effect on profit shares.
\end{abstract}

Keywords : Interest Rate, Inflation, Exchange Rate, Finance, and Advantage stock

\begin{abstract}
ABSTRAK
Saham gain optimal adalah tujuan utama investor dalam membuat investasi dalam saham perusahaan. Untuk mencapai tujuan tersebut, tentu saja, investor harus bertindak selektif dalam menilai berbagai perusahaan potensial, salah satunya adalah suku bunga, inflasi, likuiditas, nilai tukar, dan keuangan.

Tujuan pertama dari penelitian ini adalah untuk mengetahui dan menganalisis apakah suku bunga akan mempengaruhi keuntungan saham di Bursa Efek Indonesia, baik untuk belajar dan menganalisis apakah inflasi akan mempengaruhi keuntungan saham di Bursa Efek Indonesia pada periode 2010- 2012, yang ketiga untuk mempelajari dan menganalisis likuiditas mempengaruhi saham laba di Bursa Efek Indonesia pada periode 2010-2012, keempat untuk mengidentifikasi dan menganalisis nilai tukar akan mempengaruhi keuntungan saham di Bursa Efek Indonesia pada periode 2010-2012, kelima untuk megetahui dan analisis keuangan akan mempengaruhi saham keuntungan di Bursa Efek Indonesia pada periode 2010-2012, dan keenam untuk mengetahui dan menganalisis apakah inflasi, likuiditas, nilai tukar dan keuangan akan mempengaruhi saham keuntungan di Bursa Indonesia Efek pada periode 2010-2012.
\end{abstract}


Hasil penelitian ini bahwa tingkat bunga, inflasi, likuiditas, nilai tukar, dan pengaruh keuangan bersama-sama untuk mendapatkan pangsa di Bursa Efek Indonesia, sedangkan secara individu pengaruh tingkat suku bunga pada saham keuntungan.

Kata kunci: Suku Bunga, Inflasi, Nilai Tukar, Keuangan, dan Keuntungan saham

\section{PENDAHULUAN}

Return juga merupakan sebagai dasar tolakan atau ukuran tinggi rendahnya investor dalam menanamkan modalnya ke sebuah perusahaan. Artinya semakin tinggi return yang didapatkan oleh investor maka semakin besar juga investor menanamkan modal nya ke saham perusahaan, dan begitu juga sebaliknya.

Gambaran return dapat dilihat dari kondisi pasar modal, pasar modal merupakan sarana untuk mendapatkan uang guna membiayai investasi bagi sebuah emiten. Tempat untuk melakukan investasi bagi sebuah emiten adalah Bursa Efek. Berikut ini kondisi return saham atau keuntungan di Bursa Efek Indonesia 2011 sampai dengan 2012:

\section{Return/Keuntungan Saham Di Bursa} Efek Indonesia

\begin{tabular}{|c|c|c|c|c|}
\hline No & & \multicolumn{3}{|c|}{ Return (\%) } \\
\hline & Kode Saham & 2010 & 2011 & 2012 \\
\hline 1 & AALI & 15 & -17 & -9 \\
\hline 2 & ABBA & 375 & -58 & -33 \\
\hline 3 & ABDA & 73 & 48 & 138 \\
\hline 4 & ACES & 95 & 39 & 100 \\
\hline 5 & ADES & 153 & -38 & 90 \\
\hline 6 & ADHI & 122 & -36 & 203 \\
\hline 7 & ADMF & 75 & 6 & -23 \\
\hline 8 & ADMG & 60 & 170 & -37 \\
\hline 9 & ADRO & 47 & -31 & -10 \\
\hline 10 & AGRO & 19 & -30 & 25 \\
\hline
\end{tabular}

Pada tahun 2011 keuntungan saham mengalami penurunan yang sangat signifikan jika dibandingkan dengan tahun 2010, hal ini menunjukkan bahwa keuntungan saham yang dididapatkan oleh investor semakin turun, sehingga investor di pasar modal tidak akan menambah dana nya ke emiten yang mereka harapkan. Pada tahun 2012 keuntungan saham emiten di bursa efek mengalami kenaikan yang sangat baik, hal ini dapat membuat para investor menanamkan dana nya ke emiten yang mereka tuju, akan tetapi jika keuntungan saham selalu mengalami naik dan turun akan para mengkhawatirkan para investor untuk berinvestasi di bursa efek, dan sehingga akan berdampak pada perusahaan antara lain kinerja perusahaan yang tidak maksimal dalam mencapai tujuannya

Tujuan penelitian yang akan dicapai dalam penelitian ini adalah pertama untuk mengetahui dan menganalisis apakah tingkat bunga akan mempengaruhi keuntungan saham di Bursa Efek Indonesia pada periode 2010-2012, kedua untuk mengetahui dan menganalisis apakah inflasi akan mempengaruhi keuntungan saham di Bursa Efek Indonesia pada periode 2010-2012, ketiga untuk mengetahui dan menganalisis apakah likuiditas akan mempengaruhi keuntungan saham di Bursa Efek Indonesia pada periode 2010-2012, keempat untuk mengetahui dan menganalisis apakah nilai tukar akan mempengaruhi keuntungan saham di Bursa Efek Indonesia pada periode 2010- 
2012, kelima untuk megetahui dan menganalisis apakah finansial akan mempengaruhi keuntungan saham di Bursa Efek Indonesia pada periode 20102012, dan keenam untuk mengetahui dan menganalisis apakah inflasi, likuiditas, nilai tukar dan finasial akan mempengaruhi keuntungan saham di Bursa Efek Indonesia pada periode 20102012.

\section{PERUMUSAN MASALAH}

Perumusan masalah pada penelitian ini adalah:

1. Apakah tingkat bunga akan mempengaruhi keuntungan saham di Bursa Efek Indonesia pada periode 2010-2012?

2. Apakah inflasi akan mempengaruhi keuntungan saham di Bursa Efek Indonesia pada pada periode 20102012 ?

3. Apakah likuiditas akan mempengaruhi keuntungan saham di Bursa Efek Indonesia pada pada periode 20102012?

4. Apakah nilai tukar akan mempengaruhi keuntungan saham di Bursa Efek Indonesia pada pada periode 2010-2012?

5. Apakah finansial akan mempengaruhi keuntungan saham di Bursa Efek Indonesia pada pada periode 20102012?

6. Apakah inflasi, likuiditas, nilai tukar dan finansial akan mempengaruhi keuntungan saham di Bursa Efek Indonesia pada pada periode 20102012 ?

\section{TUJUAN PENELITIAN}

Tujuan penelitian ini adalah:

1. Untuk mengetahui dan menganalisis apakah tingkat bunga akan mempengaruhi keuntungan saham di Bursa Efek Indonesia pada periode 2010-2012.

2. Untuk mengetahui dan menganalisis apakah inflasi akan mempengaruhi keuntungan saham di Bursa Efek Indonesia pada periode 2010-2012.

3. Untuk mengetahui dan menganalisis likuiditas akan mempengaruhi keuntungan saham di Bursa Efek Indonesia pada periode 2010-2012.

4. Untuk mengetahui dan menganalisis nilai tukar akan mempengaruhi keuntungan saham di Bursa Efek Indonesia pada periode 2010-2012.

5. Untuk megetahui dan menganalisis apakah finansial akan mempengaruhi keuntungan saham di Bursa Efek Indonesia pada pada periode 20102012.

6. Untuk mengetahui dan menganalisis apakah inflasi, likuiditas, nilai tukar dan finasial akan mempengaruhi keuntungan saham di Bursa Efek Indonesia pada periode 2010-2012

\section{LANDASAN TEORITIS}

\section{Teori Penelitian}

\section{a. Return}

Return saham merupakan salah satu faktor yang memotivasi investor berinvestasi dan juga merupakan imbalan atas keberanian investor menanggung risiko atas investasi yang dilakukannya. Pembahasan tentang tingkat keuntungan sekuritas dapat dikelompokan dalam dua teori yaitu Capital Asset Pricing Model (CAPM) dan Arbitrage Pricing Theory (APT) (Husnan, 2005). 


\section{b. Tingkat Bunga}

Menurut Pure Exceptation Theory, tingkat suku bunga mencerminkan harapan pelaku di masa yang akan datang. Bila tingkat bunga meningkat berarti pelaku pasar keseluruhan mengharapkan bahwa dalam jangka pendek tingkat bunga akan naik. Bila tingkat bunga turun, berarti pasar mengharapkan bahwa dalam jangka pendek tingkat bunga akan turun. Jadi, besarnya tingkat bunga suatu periode ditentukan oleh harapan pelaku pasar terhadap tingkat bunga pada periode tersebut.

\section{c. Inflasi}

Inflasi adalah suatu keadaan senantiasa meningkatnya harga-harga pada umumnya, atau suatu keadaan senantiasa turunnya nilai uang karena meningkatnya jumlah uang yang beredar tidak diimbangi dengan peningkatan persediaan barang

d. Likuiditas

Menurut Fahmi (2011), likuiditas merupakan gambaran kemampuan suatu perusahaan dalam memenuhi kewajiban jangka pendeknya secara finansial dan tepat waktu sehingga likuiditas sering disebut dengan short term liquidty. Likuiditas yang dipakai pada penelitian ini adalah current ratio. Rasio ini dihitung dengan membagi aktiva dengan hutang

\section{e. Nilai Tukar}

Nilai tukar (kurs) rupiah adalah harga rupiah terhadap mata uang negara lain dalam penelitian dosen pemula ini kurs terhadap dollar AS. Kurs rupiah per dollar AS dalam penelitian ini diukur dengan kurs tengah tahunan, yaitu nilai yang diperoleh dari penjumlahan kurs jual (selling rate) dan kurs beli (buying rate) kemudian dibagi dua

\section{f. Finansial}

Finansial merupakan salah keputusan peruisahaan dalam membiayai permodalannya. Apabila semakin tinggi finansial perusahaan maka semakin kecil perusahaan akan mendapatkan suatu keuntungan.

\section{Penelitian Terdahulu}

Farkhan dan Ika (2013), melakukan penelitian dengan judul "Pengaruh Rasio Keuangan Terhadap Return Saham Perusahaan Manufaktur Di Bursa Efek Indonesia (Studi Kasus Pada Perusahaan Manufaktur Sektor Food and Beverage). Hasil penelitian menunjukkan bahwa return on asset dan price eraning ratio berpengaruh terhadap return saham, sedangkan secara simultan bahwa CR, DER, TAT, ROA dan PER berpengaruh signifikan terhadap variabel ROE tidak berpengaruh terhadap return saham.

Rusliati dan Syariah Nurul Fathoni (2011), melakukan penelitian dengan judul "Inflasi, Suku Bunga Deposito dan Return Saham Pada Industri Barang Konsumsi yang Terdaftar di BEI 2006 - 2009”. Hasil penelitian bahwa inflasi dan suku bunga deposito berpengaruh negatif dan signifikan terhadap return saham, sedangkan return pasar berpengaruh positif dan signifikan terhadap return saham Industri Barang Konsumsi yang Terdaftar Di Bursa Efek Indonesia Periode 2006-2009.

Nurhakim (2010), melakukan penelitian dengan judul "Pengaruh Perubahan Nilai Tukar, Inflasi, Suku Bunga, dan Beta Terhadap Return Saham Jakarta Islamic Index Pada Periode Bullish dan Bearish (Januari 2004 - Desember 2008). Hasil 
penelitian menunjukkan bahwa secara simultan variabel independen perubahan nilai tukar, perubahan inflasi, perubahan suku bunga dan beta berpengaruh secara signifikan terhadap return saham baik periode bullish maupun periode bearish. Pengujian parsial memberikan kesimpulan bahwa perubahan nilai tukar berpengaruh negatif dan signifikan terhadap return saham pada periode bullish dan bearish, perubahan inflasi berpengaruh negatif signifikan terhadap return saham pada periode bullish dan bearish, dan perubahan suku bunga berpengaruh negatif terhadap return saham pada periode bearish, sedangkan beta saham berpengaruh tidak signifikan terhadap return saham baik periode bullish dan bearish.

\section{METODE PENELITIAN}

Penelitian ini bersifat korelasional, yakni menjelaskan hubungan antar variabel penelitian. Penelitian ini dengan menggunakan data sekunder, yaitu berupa dokumen-dokumen dan laporan keuangan perusahaan yang berhubungan dengan penelitian ini. Data tersebut diperoleh dari website

Bursa Efek Indonesia Indonesia yang berasal dari laporan keuangan tahunan yang menjadi sampel dengan periode 2010-2012 yang di download dari website resmi Bursa Efek Indonesia yaitu www.idx.co.id.

Populasi penelitian ini adalah seluruh emiten yang terdaftar di Bursa Efek Indonesia periode 2010 sampai dengan periode 2012 sebesar 411 emiten atau perusahaan yang terdaftar di Bursa Efek Indonesia, dengan teknik pengambilan sampel penelitian dosen pemula ini adalah pertama perusahaan yang terdaftar atau listing di Bursa Efek
Indonesia 2010 sampai dengan 2012, kedua Perusahaan yang memperoleh return saham atau keuntungan saham selama periode 2010 sampai dengan 2012, dan ketiga perusahaan yang mengalami kerugian periode 2010 sampai dengan 2012.

Teknik pengumpulan data penelitian ini dengan menggunakan studi dokumentasi, yaitu dengan cara mendownload laporan-laporan keuangan perusahan yang berada di Bursa Efek Indonesia yang menjadi sampel penelitian.

Analisis data penelitian ini yaitu dengan menggunakan analisis dua analisis yang pertama dengan menggunakan analisis deskriptif dan analisis stastistika yaitu dengan menggunakan analisis regresi linier berganda.

\section{HASIL DAN PEMBAHASAN Analisis Statistika}

Sebelum dilakukannya analisis statistika dengan menggunakan analisis regresi linier berganda. Maka harus dipenuhi syarat uji asumsi klasik, berikut ini penjelasan uji asumsi klasik adalah sebagai berikut:

\section{1). Uji Normalitas}

Uji Normalitas dilakukan dengan tujuan untuk menguji apakah dalam model regresi, variabel penganggu atau residual memiliki distribusi normal (Ghozali, 2011). Ada dua teknik untuk mendeteksi apakah data berdistribusi normal atau tidak yaitu dengan menggunakan analisis grafik (scatterplot), dan analisis statistika (KolmogrovSmirnov). Berikut ini hasil pengujian asumsi klasik berdasarkan pada uji normalitas dengan menggunakan Kolmogrov-Smirnov adalah sebagai 
berikut:

One-Sample Kolmogorov-Smirnov Test

\begin{tabular}{|ll|r|}
\hline & & $\begin{array}{r}\text { Unstandardiz } \\
\text { ed Residual }\end{array}$ \\
\hline Normal Parameters a,b & Mean & 237 \\
& Std. Dev iation & .0000000 \\
Most Extreme & Absolute & .84676555 \\
Dif f erences & Positive & .195 \\
& Negative & .195 \\
Kolmogorov-Smirnov Z & & -.149 \\
Asy mp. Sig. (2-tailed) & & 3.005 \\
\hline
\end{tabular}

a. Test distribution is Normal.

b. Calculated from data.

Berdasarkan pada Tabel One sample Kolmogrov-Smirnov bahwa dapat dilihat nilai Asympg.Sig (2-tailed) dibawah 0,05 atau dibawah 5\%. Hal ini menunjukkan bahwa data tidak berdistribusi normal.
Maka peneliti melakukan logaritma natural atau Ln pada semua variabel penelitian. Berikut ini hasil uji normalitas setelah dilakukan logaritma natural atau Ln. Berikut ini hasil Ln pada uji normalitas penelitian ini adalah:

One-Sample Kolmogorov-Smirnov Test

\begin{tabular}{|ll|r|}
\hline & & $\begin{array}{r}\text { Unstandardiz } \\
\text { ed Residual }\end{array}$ \\
\hline N & & 232 \\
& & .0000000 \\
Most Extreme & Mean & 1.14036768 \\
Dif f erences & Std. Dev iation & .079 \\
& Absolute & .032 \\
Kolmogorov-Smirnov Z & Positive & -.079 \\
Asy mp. Sig. (2-tailed) & Negativ e & 1.201 \\
\hline
\end{tabular}

a. Test distribution is Normal.

b. Calculated f rom data.

\section{2). Uji Heterokedastisitas}

Uji heterokedastisitas bertujuan untuk menguji apakah dalam model regresi terjadi ketidaksamaan variance dari residual satu pengamatan kepengamatan lainnya (Ghozali, 2011).
Untuk melihat atau mendekteksi terjadi heterokedastisitas dalam penelitian ini, peneliti menggunakan grafik scatterplot, dan uji Glejser. Berikut ini hasil uji heterokedastisitas dengan menggunakan uji Glejser adalah: 
Coefficients ${ }^{\mathrm{a}}$

\begin{tabular}{|c|c|c|c|c|c|c|}
\hline \multirow{2}{*}{\multicolumn{2}{|c|}{ Model }} & \multicolumn{2}{|c|}{$\begin{array}{l}\text { Unstandardized } \\
\text { Coeff icients }\end{array}$} & \multirow{2}{*}{$\begin{array}{l}\text { Standardized } \\
\text { Coeff icients } \\
\text { Beta }\end{array}$} & \multirow[b]{2}{*}{$t$} & \multirow[b]{2}{*}{ Sig. } \\
\hline & & B & Std. Error & & & \\
\hline \multirow[t]{6}{*}{1} & (Constant) & 55.015 & 41.002 & & 1.342 & .181 \\
\hline & Ln & -.173 & .158 & -.105 & -1.097 & .274 \\
\hline & LnIf Isi & -2.410 & 1.714 & -.450 & -1.406 & .161 \\
\hline & LnLdts & .003 & .027 & .008 & .120 & .904 \\
\hline & LnN.Tkr & -6.776 & 5.055 & -.392 & -1.340 & .181 \\
\hline & LnFsl & .001 & .010 & .010 & .153 & .878 \\
\hline
\end{tabular}

a. Dependent Variable: Absut

Berdasarkan pada Tabel

Coefficient pada Uji Heterokedastisitas menunjukkan bahwa nilai Sig diatas 0,05 hal ini menunjukkan bahwa tidak terjadi gejala Heterokeastisitas pada penelitian ini.

\section{3). Uji Multikolinieritas}

Menurut Ghozali (2011), Uji

Multikolinieritas bertujuan untuk menguji apakah dalam model regresi ditemukan

Coefficients

\begin{tabular}{|c|c|c|c|c|c|c|c|c|}
\hline \multirow[b]{2}{*}{ Mode } & & \multicolumn{2}{|c|}{$\begin{array}{l}\text { Unstandardized } \\
\text { Coefficients }\end{array}$} & \multirow{2}{*}{$\begin{array}{c}\text { Standardized } \\
\text { Coeff icients } \\
\text { Beta }\end{array}$} & \multirow[b]{2}{*}{$t$} & \multirow[b]{2}{*}{ Sig. } & \multicolumn{2}{|c|}{ Collinearity Statistics } \\
\hline & & $B$ & Std. Error & & & & Tolerance & VIF \\
\hline \multirow[t]{6}{*}{1} & (Constant) & -79.564 & 64.416 & & -1.235 & .218 & & \\
\hline & $\operatorname{Ln}$ & .426 & .248 & .160 & 1.717 & .087 & .482 & 2.075 \\
\hline & Lnlf Isi & 1.852 & 2.693 & .215 & .688 & .492 & .043 & 23.398 \\
\hline & LnLdts & -.048 & .043 & -.073 & -1.120 & .264 & .991 & 1.009 \\
\hline & LnN.Tkr & 9.305 & 7.942 & .334 & 1.172 & .243 & .051 & 19.490 \\
\hline & LnFsl & .013 & .015 & .055 & .852 & .395 & .997 & 1.003 \\
\hline
\end{tabular}

a. Dependent Variable: LnK.Saham

Berdasarkan pada Tabel uji multikolinieritas bahwa nilai Tolerance ada variabelnya dibawah 0,05 dan nilai VIF ada variabelnya di atas 10 maka dapat di indikasikan terjadi gejala multikolinieritas. Berdasarkan adanya gejala multikolinieritas maka peneliti membuang variabel yang penganggu yang adanya korelasi antar variabel bebas. Untuk mendekteksi terjadinya multikolinieritas yaitu dapat dilakukan dengan meliha tolerance dan variance inflation factor, dengan asumsi yakni: 
Coefficients $^{\mathrm{a}}$

\begin{tabular}{|c|c|c|c|c|c|c|c|c|}
\hline \multirow[b]{2}{*}{ Mode } & & \multicolumn{2}{|c|}{$\begin{array}{l}\text { Unstandardized } \\
\text { Coefficients }\end{array}$} & \multirow{2}{*}{$\begin{array}{c}\text { Standardized } \\
\text { Coefficients }\end{array}$} & \multirow[b]{2}{*}{$t$} & \multirow[b]{2}{*}{ Sig. } & \multicolumn{2}{|c|}{ Collinearity Statistics } \\
\hline & & B & Std. Error & & & & Tolerance & VIF \\
\hline 1 & (Constant) & -37.088 & 18.297 & & -2.027 & .044 & & \\
\hline & $\operatorname{Ln}$ & .316 & .189 & .118 & 1.671 & .096 & .830 & 1.204 \\
\hline & LnLdts & -.048 & .043 & -.072 & -1.119 & .264 & .991 & 1.009 \\
\hline & LnN.Tkr & 4.014 & 1.972 & 144 & 2.036 & .043 & .831 & 1.204 \\
\hline & LnFsl & .013 & .015 & .054 & .843 & .400 & .998 & 1.002 \\
\hline
\end{tabular}

a. Dependent Variable: LnK.Saham

Berdasarkan pada Tabel uji multikolinieritas bahwa tidak terjadi adanya gejala multikolinieritas pada penelitian ini.

\section{4). Uji Autokorelasi}

Ghozali (2011), Uji autukorelasi bertujuan untuk menguji apakahj dalam model regresi linier berganda terhadi korelasi antara kesalahan penganggu pada periode $\mathrm{t}$ dengan kesalahan penganggu pada peruode t-1 sebelumnya. Berikut ini hasil uji Autokorelasi pada penelitian ini adalah:

Berdasarkan pada nilai DW sebesar
2.049, bahwa dapat dilihat tidak terjadi gejala Autokorelasi pada penelitian ini.

Setelah terlewati uji asumsi klasik, maka peneliti melakukan uji regresi linier berganda yang terdiri dari koefisien determinasi $\left(\mathrm{R}^{2}\right)$, uji secara bersama-sama (Uji-F), uji secara individu (Uji-t) yaitu:

\section{a. Koefisien Determinasi $\left(\mathbf{R}^{\mathbf{2}}\right)$}

Koefisien determinasi berfugsi untuk melihat sejauhmana kemampuan model dalam menjelasikan variabel dependen.

\section{Model Summary}

\begin{tabular}{|l|r|r|r|r|r|}
\hline Model & $\mathrm{R}$ & $\mathrm{R}$ Square & $\begin{array}{c}\text { Adjusted } \\
\text { R Square }\end{array}$ & $\begin{array}{c}\text { Std. Error of } \\
\text { the Estimate }\end{array}$ & $\begin{array}{c}\text { Durbin- } \\
\text { Watson }\end{array}$ \\
\hline 1 & $.243^{\mathrm{a}}$ & .059 & .038 & 1.15291 & 2.049 \\
\hline
\end{tabular}

a. Predictors: (Constant), Lnlf Isi, LnFsl, LnLdts, Ln, LnN.Tkr

b. Dependent Variable: LnK.Saham

Berdasarkan pada Tabel Model Summary bahwa nilai R-Square sebesar 0,059 atau sebesar $5.9 \%$. Hal ini menunjukkan bahwa nilai tukar, tingkat bunga, likuiditas, inflasi dan finasial hanya dapat menjelaskan variabel keuntungan saham sebesar 5,9\%, sedangkan sisanya di luar variabel penelitian ini

\section{b. Uji Secara Bersama-sama (Uji-F)}

Uji secara bersama-sama (uji-F) merupakan untuk menguji apakah tingkat bunga, inflasi, likuiditas, nilai tukar, dan finasial berpengaruh secara bersama-sama terhadap keuntungan saham di Bursa Efek Indonesia. 
ANOVAb

\begin{tabular}{|ll|r|r|r|r|r|}
\hline Model & & \multicolumn{1}{c|}{$\begin{array}{c}\text { Sum of } \\
\text { Squares }\end{array}$} & df & Mean Square & F & Sig. \\
\hline 1 & Regression & 18.823 & 5 & 3.765 & 2.832 & $.017^{\mathrm{a}}$ \\
& Residual & 300.401 & 226 & 1.329 & & \\
& Total & 319.224 & 231 & & & \\
\hline
\end{tabular}

a. Predictors: (Constant), LnIf Isi, LnFsl, LnLdts, Ln, LnN. Tkr

b. Dependent Variable: LnK.Saham

Model Summary ${ }^{b}$

\begin{tabular}{|l|r|r|r|r|r|}
\hline Model & $\mathrm{R}$ & $\mathrm{R}$ Square & $\begin{array}{c}\text { Adjusted } \\
\text { R Square }\end{array}$ & $\begin{array}{c}\text { Std. Error of } \\
\text { the Estimate }\end{array}$ & $\begin{array}{c}\text { Durbin- } \\
\text { Wat son }\end{array}$ \\
\hline 1 & $.243^{\mathrm{a}}$ & .059 & .038 & 1.15291 & 2.049 \\
\hline
\end{tabular}

a. Predictors: (Constant), LnIf Isi, LnFsl, LnLdts, Ln, LnN.Tkr

b. Dependent Variable: LnK.Saham

Berdasarkan pada Tabel uji serempak bahwa tingkat bunga, inflasi, likuiditas, nilai tukar, dan finasial berpengaruh secara bersama-sama terhadap keuntungan saham di Bursa Efek Indonesia dengan nilai signifikansi dibawah $0,05 \%$.

\section{c. Uji Secara Individu (Uji-t)}

Uji secara individu atau secara parsial merupakan untuk menguji apakah inflasi, likuiditas, nilai tukar, dan finasial berpengaruh secara individu terhadap keuntungan saham di Bursa Efek Indonesia:

\section{Coefficien ts $s^{a}$}

\begin{tabular}{|ll|r|r|r|r|r|}
\hline \multirow{2}{*}{ Model } & \multicolumn{2}{|c|}{$\begin{array}{c}\text { Unstandardized } \\
\text { Coeff icients }\end{array}$} & \multicolumn{2}{c|}{$\begin{array}{c}\text { Standardized } \\
\text { Coeff icients }\end{array}$} & \\
\cline { 3 - 6 } & \multicolumn{1}{|c|}{$\mathrm{B}$} & \multicolumn{1}{|c|}{ Std. Error } & \multicolumn{2}{|c|}{ Beta } & $\mathrm{t}$ & Sig. \\
\hline 1 & (Constant) & -79.564 & 64.416 & & -1.235 & .218 \\
& Ln & .426 & .248 & .160 & 1.717 & .087 \\
& LnIf Isi & 1.852 & 2.693 & .215 & .688 & .492 \\
& LnLdts & -.048 & .043 & -.073 & -1.120 & .264 \\
& LnN.Tkr & 9.305 & 7.942 & .334 & 1.172 & .243 \\
& LnFsl & .013 & .015 & .055 & .852 & .395 \\
\hline
\end{tabular}

a. Dependent Variable: LnK.Saham

Berdasarkan pada Tabel Uji parsial bahwa:

1. Tingkat bunga berpengaruh secara individu terhadap keuntungan saham di Bursa Efek Indonesia.

Berdasarkan pada hasil uji secara parsial bahwa nilai thitung pada tingkat bunga sebesar 1.717 dengan signifikansi sebsar 0.087 , nilai $t_{\text {tabel }}$ sebesar 1.600 dengan demikian $t_{\text {hitung }}>t_{\text {tabel }}$ dengan nilai signifikansi diatas 0,05 hal ini berarti bahwa secara individual tingkat bunga berpengaruh tidak signifikan terhadap keuntungan saham. Hal ini sejalan dengan penelitian yang dilakukan oleh Rusliati dan Syariah Nurul Fanthoni (2011), menyatakan bahwa tingkat suku 
berpengaruh terhadap keuntungan saham, hal ini dapat disebabkan oleh kenaikan tingkat suku bunga yang tinggi mengakibatkan kecenderungan investor untuk menginvestasikan uangnya ke perbankan, sehingga investasi pada saham atau surat berharga dipasar modal menjadi berkurang.

\section{Inflasi berpengaruh secara individu} terhadap keuntungan saham di Bursa Efek Indonesia.

Berdasarkan pada hasil uji secara parsial bahwa nilai thitung pada inflasi sebesar 0,688 dengan signifikansi sebesar 0,492, nilai $t_{\text {tabel }}$ sebesar 1.600 dengan demikian $t_{\text {hitung }}<t_{\text {tabel }}$ bahwa secara individual inflasi tidak berpengaruh terhadap keuntungan saham. Hasil penelitian ini tidak didukung oleh penelitian Pudyastuti (2000), Rusliati dan Syariah Nurul Fanthoni (2011), yang menyatakan bahwa inflasi tidak berhubungan terhadap keuntungan saham.

Yang menyebabkan hasil penelitian ini dengan penelitian sebelumnya bahwasanya inflasi yang naik tidak berdampak atau tidak berpengaruh terhadap keuntungan saham, hal disebabkan bahwa khususnya Negara Indonesia sebagian besar masyarakatnya memiliki perilaku konsumsi yang tinggi dibandingkan menginvestasikan dananya kepasar modal, hal tersebut menyebabkan bahwasanya inflasi yang tidak tidak dapat memberikan pengaruh terhadap keuntungan saham dalam pasar modal khususnya.

\section{Likuiditas berpengaruh secara individu terhadap keuntungan saham di Bursa Efek Indonesia}

Berdasarkan pada hasil uji secara parsial bahwa nilai thitung pada likuiditas sebesar -1.120 dengan signifikansi sebesar 0,264 , nilai $t_{\text {tabel }}$ sebesar 1.600 dengan demikian $t_{\text {hitung }}<t_{\text {tabel }}$ bahwa secara individual likuiditas tidak berpengaruh terhadap keuntungan saham. Hal ini tidak sesuai dengan hasil penelitian yang dilakukan oleh Farkhan dan Ika (2013), bahwa likuiditas berpengaruh terhadap keuntungan saham atau return saham. Yang menyebabkan pembedaan hasil penelitian ini dengan penelitian sebelumnya bahwasanya aktiva lancar perusahaan yang kecil dan tidak sebanding dengan nilai kewajiban lancar perusahaan sehingga mengakibatkan tidak naiknya keuntungan perusahaan atau protitabilitas perusahaan dan juga akan berpengaruh terhadap tingkat keuntungan saham perusahaan, dan juga investor tidak lebih memperhatikan likuiditas perusahaan sebagai dasar untuk melakukan investasi ke pasar modal

4. Nilai Tukar berpengaruh secara individu terhadap keuntungan saham di Bursa Efek Indonesia.

Berdasarkan pada hasil uji secara parsial bahwa nilai $t_{\text {hitung }}$ pada nilai tukar sebesar 1.172 dengan signifikansi sebesar 0,243 , nilai $t_{\text {tabel }}$ sebesar 1.600 dengan demikian $t_{\text {hitung }}<t_{\text {tabel }}$ sehingga nilai tukar tidak pengaruh secara parsial terhadap terhadap keuntungan saham.

Penelitian ini tidak di dukung dengan penelitian yang dilakukan oleh Nurhakim (2010), yang menyatakan bahwa nilai tukar berpengaruh terhadap return saham atau keuntungan saham, yang membedakan hasil penelitian yang dilakukan oleh Nurhakim dengan peneliti yakni pada kondisi ekonomi Indonesia pada tahun 2011 sampai dengan 2012 dalam keadaan yang sangat stabil karena kondisi fundamental ekonomi pada saat sekarang dalam keadaan yang cukup 
apabila dibandingkan dengan keadan ekonomi pada krisis moneter 1997-1998.

Pada keadaan kondisi saat ini rupiah mengalami fluktuasi yang tidak stabil sehingga kondisi pasar modal tidak menentu tentu saja investor enggan menanamkan dananya ke pasar modal sehingga tidak akan berpengaruh terhadap keuntungan saham perusahaan, investor tidak terlalu memperhatikan nilai tukar rupiah terhadap dolar untuk menginvestasikan dananya ke pasar modal khususnya.

\section{Finansial berpengaruh secara individu terhadap keuntungan saham di Bursa Efek Indonesia}

Berdasarkan pada hasil uji secara parsial bahwa nilai thitung pada nilai tukar sebesar 0.852 dengan signifikansi sebesar 0,395 , nilai $t_{\text {tabel }}$ sebesar 1.600 dengan demikian $t_{\text {hitung }}<t_{\text {tabel }}$ bahwa finansial tidak berpengaruh terhadap keuntungan saham di Bursa Efek Indonesia. Tidak adanya pengaruh finansial terhadap keuntungan saham dikarenakan sebagaian investor menganggap perusahaan yang menggunakan semua hutangnya untuk operasional perusahaan tidak akan memberikan keuntungan yang maksimal terhadap perusahaan sehingga menyebabkan tidak perolehnya keuntungan saham perusahaan.

\section{KESIMPULAN DAN SARAN}

\section{a. Kesimpulan}

Kesimpulan pada penelitian ini bahwa tingkat bunga, nilai inflasi, likuiditas, nilai tukar, dan finasial berpengaruh secara bersama-sama terhadap keuntungan saham di Bursa Efek Indonesia, sedangkan secara individual tingkat bunga berpengaruh terhadap keuntungan saham.

\section{b. Saran}

Saran dalam penelitian ini adalah:

Saran peneliti adalah diharapkan bagi peneliti dosen pemula yang akan datang hendaknya menambah waktu penelitian tidak hanya pada 3 tahun tetapi lebih 3 tahun.

\section{DAFTAR PUSTAKA}

Anggarani dan Winadi Prasetyoning Tyas, 2010. Pengaruh Rasio Likuiditas, Aktivitas, Profitabilita, Leverage dan Economic Value Addeed Terhadap Return Saham Pada Saham Food and Beverages Di Bursa Efek Indonesia. Jurnal Ekonomi, Volume 1 No.2.

Farkhan dan Ika, 2013. Pengaruh Rasio Keuangan Terhadap Return Saham Perusahaan Manufaktur Di Bursa Efek Indonesia (Studi Kasus Pada Perusahaan Manufaktur Sektor Food and Bavarage). Jurnal Value Added, Volume 9 No. 1.

Fahmi, Irham.Analisis Laporan Keuangan, Bandung: Alfabeta. 2011.

Manajemen Investasi, Jakarta: Salemba Empat. 2012.

Ghozali Imam. Aplikasi Analisis Multivariate Dengan Program IBM SPSS 19. Penerbit Universitas Diponegoro. Semarang.2011.

Kasmir. Analisis Laporan Keuangan, Jakarta: Grafindo Persada. 2012.

Madura, Jeff. Manajemen Keuangan Internasional, Jakarta: Erlangga.2000.

Noor Juliansyah. Metodologi Penerbit: Skripsi, Tesis, Disertasi dan Karya Ilmiah. Penerbit Predana Media Group. Jakarta.2011.

Nurhakim. Pengaruh Perubahan Nilai Tukar, Inflasi, Suku Bunga, dan Beta Terhadap Return Saham Jakarta Islamic Indekx Pada Periode Bullish 
dan Bearish (Januari 2004 -

Desember 2008).Skripsi. Universitas

Islam Negeri Sunan Kalijaga,

Yogyakarta.2010

Prihatini Ratna.Analisis Pengaruh Inflasi,

Nilai Tukar, ROA, DER dan CR

Terhadap Return Saham (Studi Kasus

Saham Industri Real Estate dan

Property yang Terdaftar di Bursa Efek

Indonesia Periode 2003 - 2006. Tesis.

Program Studi Magister Manajemen,

Program PascaSarjana, Universitas

Diponegoro, Semarang.2009.

Pudyastuti Enny. Analisis Pengaruh

Return Pasar, Tingkat Inflasi, Tingkat

Suku Bunga Deposito Terhadap Return

Saham Individu Pada Industri Dasar

dan Kimia yang Terdaftar di BEJ

Periode 1997 - 1999. Tesis. Program

Studi Magister Manajemen, Program

PascaSarjana, Universitas Diponegoro,

Semarang, 2000.

Rianti Suskim dan Maria Tambunan,

Analisis Pengaruh Variabel Makro

Ekonomi dan Indeks Global Terhadap

Return Saham, Jurnal Seminar

Nasional Tekonologi Informasi dan

Komunikasi Terapan, 2013.

Rusliati Ellen dan Syariah Nurul Fathoni.

Inflasi, Suku Bunga Deposito dan

Return Saham Pada Industri Barang

Konsumsi yang Terdaftar di BEI 2006

- 2009. Jurnal Bisnis dan Akuntansi

Vol 13 No. 2 Agustus 2011, Halaman

$107-118,2011$.

Samsul, M. Pasar Modal dan Manajemen

Portofolio, Jakarta: Erlangga. 2006.

Zubir, Zalmi. Portofolio Obligasi, Jakarta:

Salemba Empat. 2011. 